\title{
Epistemological Anarchism of Paul Karl Feyerabend and Medical Education
}

\section{O Anarquismo Epistemológico de Paul Karl Feyerabend e a Educação Médica}

Andréia Patrícia Gomes Rodrigo Siqueira-BatistaII Sergio Rego III

KEYWORDS:

- Knowledge;

- Methods;

- Medical Education;

- Human Resources

Formation.

PALAVRAS-CHAVE:

- Epistemologia;

- Métodos;

- Educação Médica;

- Formação de Recursos Humanos
Recebido em: 15/07/2012

Aprovado em: 11/01/2013
"The best education consists in immunizing people against systematic attempts at education."

Paul Karl Feyerabend.

\section{ABSTRACT}

The thoughts of the philosopher Paul Karl Feyerabend brought important contributions to the debate on Science in the 20th century. Most recently his views about non-existence of a single method for doing science have been employed to rethink science education and propose the use of multiple methods for effective teaching-learning process. This article employs the theoretical framework of the author expressed in the book Against Method, 1977, about the epistemological anarchism and the methodological pluralism and uses it in the contemporary discussion of medical education.

\section{RESUMO}

O pensamento do filósofo Paul Karl Feyerabend trouxe importantes contribuições ao debate sobre a ciência no século XX. Mais recentemente suas ponderações acerca da não existência de um único método para se fazer ciência têm sido empregadas para repensar a educação científica e propor a utilização de múltiplos métodos para o efetivo processo de ensino-aprendizagem. O objetivo deste artigo é empregar os referenciais teóricos do autor expressos no livro Contra o Método, de 1977, acerca do anarquismo epistemológico e do pluralismo metodológico, e utilizá-los na discussão contemporânea da educação médica. 


\section{EDUCATION AND TRAINING OF THE PHYSICIAN}

The current education of medical professionals has been rethought from the perspective of becoming a professional capable of handling the technical and scientific knowledge and ethical-humanistic perspectives, linking them to the comprehensive care of individuals and populations, in order to enhance the competence to solve the most frequent problems in his existing practice ${ }^{1}$. This position - although it may raise criticism for its air of utopia - has proved particularly necessary in view of the new shapes acquired by contemporary societies, and therefore the complexity of the problems that are in need, focusing on the health field. In this context, the doctor, after the publication of the National Curriculum Guidelines (DCN) for undergraduate courses in medicine, should have the following profile:

[...] The doctor, with generalist, humanist, critical and reflective training, able to work, based on ethical principles in the health-disease process at different levels of care with health promotion, prevention, recovery and rehabilitation of health, from the perspective of comprehensive care, with a sense of social responsibility and commitment to citizenship, as health promoter of the human being ${ }^{2}$. (p.1)

In this perspective, beyond a hegemonic model dominated by technology, often at the expense of ethics, the basic science, rather than clinical, the discipline grid, rather than the curriculum, and the imposition of a biological and historically fragmented vision, consisting in medical schools as a result of the Flexner Report (1910) ${ }^{3}$, it is essential that the undergraduate courses allow students to experience, critically, the processes of knowledge construction, as well as to broaden their perspective to other aspects in addition to the scientism, toward a performance-based care for people and populations ${ }^{4}$. Considering that higher education not only has the goal of training a professional for a particular job and also to seek to educate citizens, especially in a country strengthened by universal access to health, clearly put in its carta magna ${ }^{5}$, to create possibilities for the development and strengthening of autonomy, social and ethical vision of his practice, necessary to deconstruct the old theory / practice dichotomy, it becomes essential the implementation of the changes proposed by the National Curriculum Guidelines for Undergraduate Courses in Medici$\mathrm{ne}^{2}$ and the Organic Law of Health ${ }^{6}$. However, even today, the majority of medical courses have their workload organized in order of priority, in the form of lectures (mere "transmission" of knowledge), which maintains the student with a supporting role in the teaching-learning process ${ }^{7}$. The consequences of this situation do not take long, having great impact in a short time, in the understanding of everyday situations of health and illness, in addition to underestimating any joint reflection, since the teacher is the one who holds the knowledge. The concepts and the different models that structure medical knowledge are then repeated, memorized, but not applied long enough to encourage reflection, since the model is applied to a pedagogy of council transmission ${ }^{8}$, estranging the student from practice and approaching him to the disciplinary grids literally trapping him in a curricular structure that favors the disciplines, culminating in an insufficient training for work in the multifactorial and complex reality of the health-disease process. ${ }^{9,10}$. The personal characteristics and the various biographies are not taken into consideration, students must learn by following the same method, sealed, which in many circumstances cause the doctors, after their graduation, to look at organs, systems, enzymes and diseases and not people who are sick and need help.

In an attempt to respond to hegemonic medical training, emerged as a proposal for improving the quality of education - in line with DCN ${ }^{2}$, the PRO-PROMED ${ }^{11}$ and PRÓ-SAÚDE ${ }^{12}$, the adoption of active methods of teaching and learning (MAE), focusing, then, the process in the student and reaffirming the commitment of this with his learning ${ }^{13}$, believing that with such a methodological change, one can approach the doctor in training that doctor recommend by DCN. Certainly, the idea of methodological change - from traditional to problem-based learning, isolated and as a replacement - is surprisingly reductive and attributed to a methodological role change and a result which undoubtedly, he cannot achieve alone. In fact, ultimately it is a misconception of the same nature: return to lecture situations by processing problems.

It opens from the above observations, the perspective of considering the introduction of a new viewpoint on the issue: one can apply the proposed teaching of pluralism in the teaching of medicine, whose inspiration can be found in the work of Karl Paul Feyerabend ${ }^{14}$. This strategy, known as entered in epistemological anarchism, has at its core the defense of methodological pluralism, a criticism to a universally valid principle for doing science:

The idea that science can and must be approached in obedience to fixed and universal rules is chimerical and pernicious. It is chimerical because it implies too simplistic vision of man's capacities and circumstances that cause or stimulate development. And it is pernicious because the attempt to lend validity to the rules leads to enhance our professional qualifications at the expense of our humanity. Moreover, the idea is detrimental to science because it leads to ignoring the complex 
physical and historical conditions which influence scientific evolution. [...] All methods have limitations and only the rule of anything goes is able to keep up ${ }^{14}$.(p. 449)

Understanding that the criticism is directed at the feyerabendian method, deconstructing the idea that it is universal there is room to assume the existence of a multiplicity of paths to follow (method, etymologically from the Greek odos, path). The anarchist and pluralistic epistemology of Feyerabend - or rather, his methodological pluralism - has significant pedagogical implications. These can assist in discussions of education, and in the case of this work, medical education, proposing a pedagogical model sprinkled with multiple views of the way.

The aim of this paper is to discuss the theoretical contributions of Feyerabend's thinking for medical education, proposing, then the use of educational pluralism.

\section{PAUL FEYERABEND AND THE SHADES OF EPISTEMOLOGICAL ANARCHISM TEORY}

The epistemological anarchism merges with the thought of Feyerabend ${ }^{15}$. In fact, one can say that its formulations are in anarchism - a term of Greek origin: anarchia can be "decomposed" in an (denoting negation) and arche (word with multiple meanings: "start", "starting point", "origin", "principle", "material cause", "foundation", "power", "authority", "title", "judiciary", "kingdom"), referring to the idea of non-government - its conceptual bases. In the context of political thought, anarchism refers to a way of life without a state - this modern idea - was an idea forged in the late $19^{\text {th }}$ century ${ }^{16}$.

Anarchism has many streams, but in one way or another, all focus on the defense of individual liberty against the different forms of exercise of power and coercion, subjecting dogma and rigid theory systems ${ }^{17}$. Feyerabend, in his discussion of science, argues against the adoption of an inflexible methodological procedure, single and narrow, with rules that are intended to be usable in any situation, that is, universal, unconditionally able to legitimize the scientific know-how, placing it as the final horizon for any field that aims knowledge ${ }^{18}$.

In fact, it is not, however, to refute any possibility of scientific method, but to recognize that it has limitations from the moment one applies the same logic method in different situations and contexts and, in general, the most diverse cultural traditions are able to contribute to scientific activity, as stated:

Science is one of the many forms of thought developed by men and not necessarily the best. It draws attention, is noisy and inconsiderate, but not inherently superior to the sight of those who had already decided in favor of a certain ideology or who already have accepted it, without even examining their convenience and limitations ${ }^{19}$. (p. 447)

Given this perspective, the author establishes a dialogue with the Western rationalist tradition, criticizing it for having replaced the rich plurality of "theorist" procedures that come from different spheres of the principle which makes the abstract unity of knowledge and uniformity of its argumentative procedure and always looking for justification ${ }^{19}$. So, finally, he presents arguments for the non-superiority of science:

[...] if science is really a set of different approaches, some successful, others completely speculative, then there is reason to despise what happens outside. Many traditions and cultures, some of them extraordinarily "unscientific" (they are addressed to the deities, consult oracles, perform "meaningless" rituals to purify body and soul) have succeeded in making it possible that its members live a rich and moderately full life ${ }^{20}$. (p. 232)

The feyerabendian critique approached a very limited conception of science, which is reduced to mere calculation and application of a valid method in any circumstance. On the other hand, it found that scientific activity is quite peculiar, or a scientific experiment is something specific ("discover" the unknown, corroborate a hypothesis) and that cannot be considered "imperialistically" as a model for any other type of experience, since that would only be valid in the event in its own context.

It is conceivable, therefore, that political anarchism means to the state, what epistemological anarchism means to reason (in a limited conception) ${ }^{15}$, however, one should not confuse the positions taken by Feyerabend with mere irrationalism - as considered by some authors ${ }^{21}$ - since the thinker, writing Against Method, did not intend to stand against science as an activity, but rather against rigid conception of some scientists, recognizing that there is no immutable methodological rules, which govern the progress of science or knowledge acquisition. In addition:

[...] wanted to protect scientists against unreasonable limitations, [given that there cannot be] a certain set of rules to make scientific discoveries, nor have them to make a great opera or a good film ${ }^{19}$. (p. 134)

Thus, rather than a renouncement of any form of methodological procedure, it subscribes to an initiative from 
attempts to establish a set of standards, intended to be universally valid, and whose immediate effect is the distinction between what is defined as "science", "scientific" and what is "non-science", "unscientific".

Inspired by humanistic principles, the philosophical critique of Feyerabend insists that historical research leaves no margin to doubt any set of rules established once and for all to define the development of scientific activity, since such a procedure has been repeatedly proven to be violated ${ }^{14}$. In fact, it seems to be possible to combine fixed and universally valid principles about what the study of history of science indicates. To the epistemologist, scientific thinking, in its most fruitful move is in the attention of the circumstances and not in respect to a single method. As it seeks to explain the development of science not only admits, but often requires the introduction and defense of hypotheses ad hoc ${ }^{14}$.

Thus, the discussion of the historical development and direction of science is structured to issues of cultural, political, social and religious importance. Feyerabend's pluralistic epistemology, as previously discussed, has significant pedagogical implications, as proposed in the following considerations.

\section{EPISTEMOLOGICAL ANARCHISM AND EDUCATION: OUTLINING FOR PEDAGOGICAL PLURALISM}

The diversity of cultures and experiences of students makes choosing a unique pedagogical model - whatever it is - an arduous task, fated, almost invariably to failure. In fact, depending on the cultural capital incorporated ${ }^{22}$ we will have different types of learners, and, given these differences, many styles of training ${ }^{23.24}$. Laburú questions educational activities based on a unique pedagogical model, which would certainly be appropriate for some, but ineffective or less effective for the other group members. Thus, the proposed use of a plurality of metho$\mathrm{ds}$, make the school - in this case medicine - more attractive to most students, going beyond the application of a single model - hegemony - of thought. The plural form of thinking / acting education expressed the ideas of epistemological anarchism, in that it accepts and examines different concepts, assuming that the descriptions and the teaching-learning, depending on who was the observer and the clipping that one wishes to describe, can obscure other realities ${ }^{18}$. That is, just like the feyerabendian philosophy presupposes the absence of the primacy accorded to scientific explanations in relation to other ways of seeing the world, pluralistic pedagogical education should not cling dogmatically to a particular method or mode of teaching, which characterizes a "dictatorship of the method."

For Feyerabend contemporary science education has the status of training, or even exercising. This approach - he states
- is inhibiting creativity, to the extent that it precludes the imagination through the diffusion of fear of factors outside their sphere of knowledge - mystical and religious doctrines, and other popular knowledge - cause obscurities that may obstruct the scientific development. One consequence, however, to this method is the dictatorship of the adoption of a supposed independence and neutrality of the learner, gradually eliminating the constitutive aspects of sensitivity regarding others ${ }^{25}$. To be successful in the world bounded by this tradition of thought, the scientist should - presumably - get a total neutrality in its own way, getting rid of religious commitment, political and cultural as well as the position in medical school, in which the professional (a scientist) learns to move away from the patient, to classify it as an object of study, to seek the (impossible) neutrality in the face of pain, suffering and finitude, transforming the human being who uses it for solving a problem in the disease, i.e., in science.

But if the desire for change in education comes from the desire to ally with the technical-scientific quality and ethical and humanistic aspects, there is need for a genuinely humanistic and progressive education from childhood ${ }^{26}$, enabling the development of the wealth of possibilities of the future man / woman and making him able to build and insert into reality:

Progressive educators have always tried to develop the individuality of their disciples, to ensure that the talents and convictions in order to bear fruit to personal talents and convictions and sometimes the only ones that a child possesses. However, such an education has been seen often as a futile exercise, comparable to daydreaming. Indeed, it is not necessary to prepare the young for life as it truly is? [...] At the end, this process will not lead to a divorce between the hated reality and scrumptious fantasies, between science and art, between the description and cautious unrestricted self-expression? The arguments in favor of plurality show that this need not happen. We must conserve what deserves the name of freedom of artistic creation and use it widely not only as a path of escape, but as a necessary element to discover and, perhaps, change the features of the world around $\mathrm{us}^{14}$. (p. 71)

Since we speak here of adult education and part-time in an undergraduate course - such as medicine, which lasts for six years - is limited, it cannot be lost, perhaps unique opportunity to sediment the concept of education as capable of changing man. It is conceived, therefore, a broader sense of 
human training and participation in the life and growth of society, allowing them not only information, but the formation of citizens engaged in the construction of social changes that Brazil's situation requires of a health care professional.

Thus, Feyerabend mentions repeatedly throughout Against Method, that it is essential to find a humanistic orientation to contemporary science and education. Instead of articulating the problem of knowledge - and more specifically the problem of scientific knowledge - the traditional categories of rationalistic thought such as "truth", "justice" and "universal method", among others, seek to guide you through a paradigm of humanity. A careful reading of their work allows to characterize it as an ideal to search for the free development of the subject, from the refusal of submission to a single standard or method of training.

Let's look at the possible consequences of these ideas for medical education.

\section{MEDICAL EDUCATION: EPISTEMOLOGICAL ANARCHISM AND EDUCATIONAL PLURALISM}

The traditional teaching method - which includes such practices as the use of the blackboard (and their substitutes: transparencies, slides, and other data show) - is the hegemonic method used in undergraduate courses in Medicine. Even those classes given by teachers endowed with great knowledge, as a result carry the potential for very low retention of contents in the construction of the learning process.

Among the proposed alternatives for achieving more effective results are the methods that are inspired by constructivism - these understood as any ideas or doctrines that emphasize the role of the knower (epistemic subject) in the construction of reality known (epistemic object) -, in their different molds. The primary method in use by schools undergoing curriculum change in Brazil and the world is the Problem-Based Learning (PBL), a philosophy considered curricular ${ }^{27,28}$, whose inspiration can be sought in John Dewey ${ }^{29}$. It was conceived in Canada in the 60s, at McMaster University and pioneer institutions like the University of Maastricht, the Netherlands and Newcastle in Australia and has spread to the world, arriving in Brazil in late 1990, Marilia and Londrina ${ }^{30,31.32}$, and spread to numerous institutions of higher education as a strategy of transforming medical education. That is what is intended with the use of PBL: creating opportunities for active learning while modeling professional attributes and attitudes that form a better doctor ${ }^{33}$, using a method enjoyable and fun, and motivating ${ }^{34}$.

It is not this, however, what could be seen when, in 1993, Albanese and Mitchell ${ }^{35}$ came to the conclusion that there was no cognitive gain when comparing students who used PBL curricula to those who used the traditional methodology and suggested that there was parsimony in making curricular changes $^{35}$. Albanese ${ }^{36}$ returned to the issue, pointing out the lack of scientific evidence of the superiority of the method of PBL, and released, however, a question looming: the spread of the PBL is something that suggests the superiority of the method. That is, it was used a fallacy to maintain their loyalty to the expected change in the profile, when instituted a methodological change, despite the initial idea had not secured the expected changes.

It is clear the possibility of the need for a new proposal for tutoring medicine courses, since the commitment to change from one method to another (traditional PBL) does not seem sufficient ${ }^{37}$. Opens, then the possibility of alternatives such as educational pluralism. It must be said that the development of isolated activities without establishing meanings and intersections do not mean to be acting in a pluralistic way. For that reality to be constructed in a manner most appropriate undergraduate courses in medicine need to review the philosophies and goals of training, need to foster discussion among its faculty and students. There should be created room in their curricular areas for training, reflection and research, using several different methods in the pursuit of integration and interdisciplinarity in the construction of knowledge.

The adoption of these educational guidelines demand, in principle, a training effort, beyond the desire of deployment. It's a long process of paradigm change with the opening to new possibilities which are less close than the majority of teachers has been doing in their practice. It is discussed that the multiple strategies such as encouraging reading, creating problem situations, generating conflicts based on empirical and conceptual contradictions at different levels, discussions with arguments grounded in theory, the construction of concept maps, exhibits, seminars, laboratory classes, activities for inclusion in the services, the questioning, among other widely used, should be encouraged in "classroom" ${ }^{1}$. The teaching tools and methodologies should be used in the search for better understanding and learning, shamelessly framing one or another current methodology, approaching the teaching of learning.

The teacher who adopts pedagogical pluralism, then, constantly examines the proposals for teaching, innovating, taking risks and experimenting in his classroom. The teaching will be oriented in terms of quality of learning and knowledge of students, committed to the enrichment of personal and social experiences of the students.

\section{FINAL CONSIDERATIONS}

The considerations presented here allow us to rewrite pedagogically, to paraphrase Feyerabend, the text of Against Method mentioned in the Introduction, in the following terms: 
The idea that medical education can and should be elaborated in obedience to fixed and universal rules is both chimerical and pernicious. It is chimerical because it implies too simplistic vision of man's capacities and circumstances that cause or stimulate development. It is pernicious because the attempt to lend validity to the rules leads to enhance our professional qualifications at the expense of our humanity. Moreover, the idea is detrimental to medical education because it leads to ignoring the complex physical and historical conditions that influence the evolution of scientific and health work. ${ }^{14}$

Thus, for pedagogical pluralism is not just another format (or superficial attempt to change) - with a consequent paradoxical practice - pluralism must be understood in its conception. If there are no pre-established rules, it is necessary to respect the individual interpretation that the other has made of his environment, the teacher should not try to format the student's response to their own expectations. Living pluralism and then applying it in teaching practice is also looking beyond the method. Showing the possibility of inclusion of the knowledge currently scorned by its non-scientificity, such as homeopathy and acupuncture, which despite being considered medical specialties, are not usually taught in medical school.

Therefore, the criticism of Feyerabend is that the prospect of considering the method as the absolute path to the truth can be extrapolated to education when considering educational transformations, which has been effected in medical education, disadvantaging the multiplicity of learning processes and therefore, the way to better health care.

\section{REFERENCES}

1. Rego S, Gomes AP, Siqueira-Batista R. Bioética e Humanização como temas transversais na formação médica. Rev Bras Educ Med. 2008;32(4):482-91

2. Brasil. Ministério da Educação. Conselho Nacional de Educação. Câmara de Educação Superior. Diretrizes Curriculares Nacionais do Curso de Graduação em Medicina. Resolução CNE/CES no. 4, de 7 de novembro de 2001. Institui Diretrizes Curriculares Nacionais do curso de graduação em Medicina. Diário Oficial da União. Brasília, 9 nov. 2001; Seção 1, p.38.

3. Flexner A. Medical Education in the United States and Canada. New York: Carnegie Foundation for the Advancement of Teaching; 1910. (Bulletin, 4).

4. Siqueira-Batista R. O cuidado integral em questão: diálogos entre filosofia e medicina (Editorial). Brasília Médica. 2010;47(3):273-5.

5. Brasil. Constituição da República Federativa do Brasil. São Paulo: Ed. Revista dos Tribunais; 2000.
6. Brasil. Ministério da Saúde. Lei no 8.080, Lei Orgânica da Saúde, de 19 de setembro de 1990. Dispõe sobre as condições para a promoção, proteção e recuperação da saúde, organização e o funcionamento dos serviços correspondentes e dá outras providências. Brasília: Diário Oficial da União. Brasília,19 de setembro de 1990.

7. Siqueira-Batista R, Siqueira-Batista R. Os anéis da serpente a aprendizagem baseada em problemas e as sociedades de controle. Ciênc Saúde Coletiva. 2009;14(4):1183-92.

8. Freire P. Pedagogia da Autonomia. Rio de Janeiro: Paz e Terra; 1996.

9. Gomes AP, Dias Coelho UC, Cavalheiro PO, Gonçalvez CAN, Rôças G, Siqueira-Batista R. A educação médica entre mapas e âncoras: a aprendizagem significativa de David Ausubel, em busca da arca perdida. Rev Bras Educ Med 2008;32(1):105-11.

10. Cotta RMM, Gomes AP, Maia TM, Magalhães KT, Marques ES, Siqueira-Batista R. Pobreza, injustiça e desigualdade social: repensando a formação de profissionais de saúde. Rev Bras Educ Med. 2007;31(3): 278-86.

11. Brasil. Ministério da Saúde. Ministério da Educação. Secretaria de Políticas de Saúde. Secretaria de Ensino Superior. Programa de Incentivo a Mudanças Curriculares nos Cursos de Medicina: uma Nova Escola Médica Para Um Novo Sistema de Saúde. Brasília; 2002.

12. Brasil. Ministério da Saúde. Ministério da Educação. Pró-Saúde: Programa Nacional de Reorientação da Formação Profissional em Saúde. Brasília: MS; 2005.

13. Mitre SM, Siqueira-Batista R, Girardi-de-Mendonça JM, Morais-Pinto NM, Meirelles CAB, Pinto-Porto C, Moreira T, Hoffmann LMA. Metodologias ativas de ensino-aprendizagem na formação profissional em saúde: debates atuais. Ciênc Saúde Coletiva. 2008;13(2):2133-214.

14. Feyerabend PK. Contra O Método. Tradução de Octanny S. Da Mota e Leônidas Hegenberg. Rio De Janeiro: Livraria Francisco Alves; 1977.

15. Siqueira-Batista R, Siqueira-Batista R, Schramm FR. A ciência, a verdade e o real: variações sobre o anarquismo epistemológico de Paul Feyerabend. Cad Bras Ens Física. 2005;22(2):240-62.

16. Vincent A. Ideologias Políticas Modernas. Tradução Ana Luísa Borges. Rio de Janeiro: J. Zahar; 1995.

17. Woodcock G. História das idéias e movimentos anarquistas. Vol 1. A Idéia. Porto Alegre: L \& PM; 2007.

18. Regner ACKP. Feyerabend e o pluralismo metodológico. Cad Catar Ens Física. 1996;13(3):231-47.

19. Toulmin S. Regreso a la razón. El debate entre la racionalidad y la experiencia y la práctica personales en el mundo contemporáneo. Barcelona: Ediciones Península; 2003. 
20. Feyerabend PK. La conquista de la abundancia. Traducción de Radamés Molina y César Mora. Barcelona: Paidós; 2001.

21. Oliva A. Anarquismo e conhecimento. Rio de Janeiro: J. Zahar; 2005.

22. Bourdieu P. Os três estados do capital cultural. In: Nogueira MA, Catani A. organizadores. Escritos de Educação. 7aed. Petrópolis: Vozes;1998. p.71-9.

23. Kempa R, Diaz M. Motivational traits and preferences for different instructional modes in science. Part 1: students motivational traits. Intern J Sci Education. 1990;12(2):194-203.

24. Laburú CE, Carvalho M. Controvérsias construtivistas e pluralismo metodológico no Ensino de Ciências Naturais. Rev Abrapec [periódico na Internet]. 2001 [acesso em 10 jun. 2010];1(1). Disponível em: http:/ /www.fae.ufmg.br/ abrapec/revistas/v1n1a5.pdf

25. Siqueira-Batista R, Schramm FR. A bioética da proteção e a compaixão laica: o debate moral sobre a eutanásia. Ciênc Saúde Coletiva. 2009;14(4):1241-50.

26. Terra PS. O ensino de ciências e o professor anarquista epistemológico. Cad Bras Ens Fís. 2002; 19(1):208-18.

27. Cézar PHN, Guimarães FT, Gomes AP, Rôças G, Siqueira-Batista R. Transição paradigmática na educação médica: um olhar construtivista dirigido à aprendizagem baseada em problemas. Rev Bras Educ Med. 2010;34(3):298-303.

28. Penaforte J, Schmidt H, Caprara A, Tomaz JB, Sá H, organizadores. Aprendizagem baseada em problemas: anatomia de uma nova abordagem educacional. São Paulo: Hucitec; 2001.

29. Dewey J. Democracia e educação. Trad. Godofredo Rangel e Anísio Teixeira. 3aed. São Paulo: Nacional; 1959.

30. Zanolli M. Metodologias ativas de ensino-aprendizagem na área clínica. In: Marins JJN, Rego S, Lampert JB, Araújo JGC, organizadores. Educação médica em transformação: instrumentos para a construção de novas realidades. São Paulo: Hucitec; Rio de Janeiro: Abem; 2004.

31. Venturelli J. Educación Médica. Novos enfoques, metas y métodos. 2ª ed. Washington: OPAS; 2003.
32. Schimidt HG. Problem-based learning: rationale and description. Med. Educ. 1983;17:11-6.

33. Gordon J. ABC of learning and teaching medicine: one to one teaching and feedback. BMJ. 2003;326: 543-5.

34. Davis MH, Harden RM. AMEE Medical Education Guide no. 15. Problem-based learning: a practical guide. Med Teacher. 1999;21(2):130-40.

35. Albanese MA, Mitchell S. Problem-based learning: a review of literature on its outcomes and implementation issues. Acad Medicine. 1993;68:52-81.

36. Albanese MA. PBL learning: why curricula are likely to show little effect on knowledge and clinical skills. Med Educ. 2000;34:729-38.

37. Gomes AP. (Trans) formação da educação médica: é possível mudar o perfil do egresso com base em modificações no método de ensino-aprendizagem? [Tese]. Rio de Janeiro: Escola Nacional de Saúde Pública Sergio Arouca, Fiocruz; 2011.

\section{AUTHORS' CONTRIBUTION}

Andreia Patricia Gomes participated in the ideation, development, writing of the first and final draft of the article. Sergio Rego guided every step of the work and conducted a critical review. Rodrigo Siqueira-Batista participated in the writing and critical review, particularly of topics 2 and 3. All authors participated in the final draft.

\section{CONFLICTS OF INTEREST}

Sergio Rego é editor da Revista Brasileira de Educação Médica

\section{CORRESPONDENCE ADDRESS}

Andréia Patrícia Gomes

Universidade Federal de Viçosa

Departamento de Medicina e Enfermagem

Avenida Peter Henry Rolfs, s/n

Campus Universitário

36570-000 - Viçosa - MG

E-mail: andreiapgomes@gmail.com 